\title{
Alien species in different habitat types of Slovenia: analysis of vegetation database
}

\author{
FILIP KÜZMIČ1 \\ URBAN ŠILC ${ }^{1,2}$, \\ ${ }^{1}$ ZRC SAZU (Research Centre of the Slovenian \\ Academy of Sciences and Arts), Institute of Biology, \\ Novi trg 2, 1000 Ljubljana, Slovenia \\ ${ }^{2}$ BC Naklo, Strahinj 99, 4202 Naklo, Slovenia \\ Correspondence: \\ Urban Silc \\ E-mail: urban@zrc-sazu.si
}

Key words: neophytes, archaeophytes, habitat types, EUNIS

Received May 05, 2017.

Revised August 29, 2017.

Accepted September 06, 2017.

\begin{abstract}
Background and purpose: Invasion by alien plant species is considered as one of major threats to biodiversity. Actual invasion of different habitats in particular country is important for understanding processes that are important in invasion ecology as well as for the nature conservation.
\end{abstract}

Materials and methods: Vegetation relevés stored in a database Vegetation of Slovenia were translated into 30 EUNIS habitat types which enables comparison with similar studies in other European countries. Out of the 18606 plots stored in the database stratified resampling yielded 6517 relevés. For each vegetation plot we calculated mean relative species richness per plot and total cover of archeophytes, neophytes and native species.

Results: Most invaded habitat type with the highest species percentages of alien species (archaeophytes and neophytes) is arable land (II). In addition, archaeophytes occur in higher percentages in trampled areas, anthropogenic herb stands, mesic grasslands, and moist tall-herb stands. Neophytes are on the other hand highly represented in arable land, trampled areas, but also riverine scrubs and wet and moist tall-herb stands.

Conclusions: Pattern across different regions in Europe is very similar with anthropogenous habitats being the most invaded by alien species.

\section{INTRODUCTION}

$A$ lien species have become a major interest of the research commuAnity because they pose a threat to local biodiversity, especially when they invade natural vegetation. Alien species are species that occur in certain area as a result of accidental or intentional introduction based on human activity (1). Many alien species appear only ephemerally, even require repeatable human introductions and are called casual alien species (or ephemerophytes). Naturalized alien species are successfully establishing stable/permanent populations and in some cases become invasive by reproducing and spreading over large areas. Part of invasive species become transformers by changing natural plant communities or even ecosystems $(1,2)$. Native species on the other hand are species that have origin in particular area and are present there without human impact or has arisen de novo in the area (3). Their natural areal is conditioned by natural characteristics.

According to the residence time (the time since introduction) we classify an alien species either as an archaeophyte (introduced before $1500 \mathrm{AD}$ ) or as a neophyte (introduced after $1500 \mathrm{AD})(4,5)$. Classification of an archaeophyte species is less clear than neophyte species although both categories are well defined. Classification of species as archaeophytes can be fuzzy and different researchers classify same species 
into different categories. Usually species are not classified based on evidence (paleobotanical or fossil) and intuition or uncritical copying of older sources is present (3). Distinction is especially difficult in the south of Europe as most of archeaeophytes originate from southern Europe or Middle East (G). Archaeophytes are present since their arrival accompanying humans in the region for hundreds or even thousands of years, have become well adapted and are included into plant communities, whereas neophytes still immigrate, occupy different habitats and expand their areal (7). On the contrary some archaeophytes are experiencing shrinking of their newly acquired territory because of the loss of suitable habitats (such as intensification of farming) $(8,9)$.

Growing amount of floristic and vegetation data enables quantitative assessment of level of invasion of alien species in different habitats (10). In the last decade some studies, using large vegetation databases, have dealt with this question on regional (11-17) or continental scale (18) and they have found major differences with regard to residence time of alien species and different characteristics of particular habitat types, but also altitude and time.

In Slovenia there have been two papers published dealing with alien plant species on a national scale. Jogan, et al. (19) published a list of Slovenian alien plant species with data on first recording, present distribution, estimations of naturalization, frequency of occurrence and trends. They had classified alien species into two groups according to the time of introduction: as archaeophytes or neophytes. Archaeophytes were further divided into two categories: most probable (97 species) and potential archaeophytes (127 species) because of before-mentioned lack of direct evidence for such species.

In addition a list of nationally important invasive species list has been formed. According to this list Zelnik (20) analysed frequency of invasive species in particular habitats (not using EUNIS classification), using 3500 floristic records. He also evaluated the potential of these species for further invasion in habitats. More focus has been put on analysing synanthropic vegetation that is highly susceptible to invasion by alien plant species (21-23).

The aim of the present study is to test data from Slovenian vegetation database (24) to analyse the presence of most widespread alien species in various habitats, find the level of invasion of different plant communities and to compare our results to patterns in other European studies.

\section{Study area}

Slovenia is a transient country between central and south-eastern Europe (the Balkans) from $46^{\circ} 52^{\prime} 36^{\prime \prime}$ to $45^{\circ} 25^{\prime} 19^{\prime \prime} \mathrm{N}$ and from $13^{\circ} 22^{\prime} 32^{\prime \prime}$ to $16^{\circ} 36^{\prime} 38^{\prime \prime} \mathrm{E}$. On an area of $20273 \mathrm{~km}^{2}$, Slovenia has been phytogeographically divided according to climate into: submediterranean, prealpine, alpine, predinaric, dinaric and subpannonian region (25). According to diverse topography (altitudes 0-2 $864 \mathrm{~m}$ a.s.l.) precipitation values range from less than $900 \mathrm{~mm}$ in the northeast subpannonian region to more than $3200 \mathrm{~mm}$ in the Alps. Similarly, mean annual temperatures range from around $0{ }^{\circ} \mathrm{C}$ in the Alps to over $12^{\circ} \mathrm{C}$ in the coastal region (26).

The characteristics mentioned are reflected also in floristic and vegetation diversity. Although most of the country's area is covered by forests many other vegetation types are found - from species poor mires, bogs and saline vegetation through diverse grasslands to alpine habitats. Šilc and Čarni (27) listed 588 plant associations recorded in Slovenia, belonging to 51 classes. Flora of Slovenia comprises 3452 taxa (28). Assessment of alien species of Slovenia lists 343 neophytes (including casual aliens e.g. ephemerophytes) and 224 archaeophytes (most probable and potential ones), which means that about $10 \%$ of Slovenian flora is alien to the area (19).

\section{Methods}

We used vegetation dataset from Vegetation database of Slovenia (24) in Turboveg software (29) where vegetation plots sampled according to Braun-Blanquet (30) method are stored. Vegetation plots of all vegetation types were selected that were attributed to syntaxa by original authors. To avoid oversampling of particular areas or vegetation types we performed stratified resampling: one relevé of one particular association from one plot $(0.75 \mathrm{x}$ 1.25 degrees) was selected. If more relevés complied with the selection terms one was randomly selected. This yielded 6517 relevés out of 18606 stored in database in December 2015. For each relevé list of species, altitude, plot size and habitat was exported.

For interpretation of phytosociological syntaxa to EUNIS habitat we used crosswalk between two hierarchical typologies (alliances and habitat types) by Schaminée, et al. (31). Each vegetation plot was assigned to one of 71 unique EUNIS habitat types and subsequently narrowed to 30 habitat types (Table 2). We assigned them to Level 2 , but in some cases Level 3 was used where subtypes with different invasion levels were included and to allow comparison with results of Chytrý, et al. (11). There is a distinction in classification of ruderal vegetation between previous studies $(11,14)$, where annual ruderal vegetation was classified within J6 habitat type (Waste deposits), while recently (31) all ruderal vegetation is classified as E5.1 (Anthropogenic herb stands).

Cryptogams and species determined to genus level were deleted and species in various strata were merged into one. Taxonomy and nomenclature of plant species are in accordance with Martinčičc, et al. (28) and syntaxa in accordance with Šilc and Čarni (27). Closely related species and taxonomically difficult for determination were aggregated according to Martinčič, et al. (28). For listing of archaeophyte and neophyte species we used classification by Jogan, et al. (19). For further analyses we used only the group of most probable archaeophytes. For each veg- 


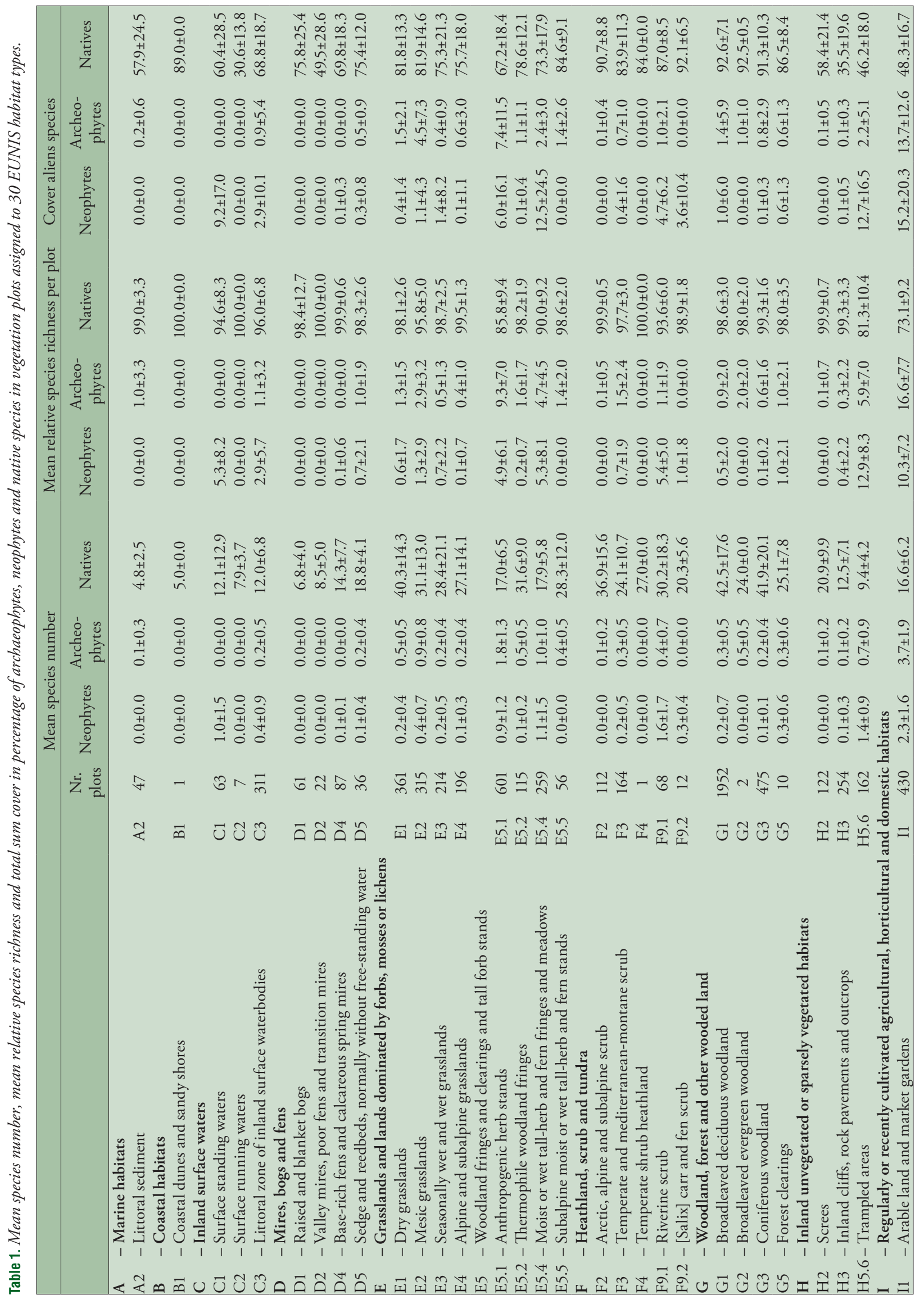


Table 2. Fifteen neophytes and archaeophytes in vegetation of Slovenia that occur in the highest number of different EUNIS habitat types. Species are sorted from highest number of occupying habitats downwards.

\begin{tabular}{|c|c|c|c|c|c|}
\hline Neophytes & $\begin{array}{l}\text { Number } \\
\text { of EUNIS } \\
\text { habitats }\end{array}$ & Archaeophytes (most probable) & $\begin{array}{l}\text { Number } \\
\text { of EUNIS } \\
\text { habitats }\end{array}$ & Archaeophytes (possible) & $\begin{array}{c}\text { Number } \\
\text { of EUNIS } \\
\text { habitats }\end{array}$ \\
\hline Erigeron annuus & 17 & Dactylis glomerata & 20 & Trifolium repens & 17 \\
\hline Solidago gigantea & 16 & Cirsium arvense & 14 & Corylus avellana & 15 \\
\hline Conyza canadensis & 11 & Cynodon dactylon & 7 & Cirsium vulgare & 13 \\
\hline Rudbeckia laciniata & 11 & Setaria pumila & 7 & Picris hieracioides & 13 \\
\hline Galinsoga parviflora & 10 & Amaranthus lividus & 5 & Arrhenatherum elatius & 12 \\
\hline Oxalis fontana & 9 & Euphorbia helioscopia & 5 & Verbena officinalis & 12 \\
\hline Ambrosia artemisiifolia & 8 & Castanea sativa & 4 & Cichorium intybus & 11 \\
\hline Impatiens glandulifera & 8 & Portulaca oleracea & 4 & Rumex crispus & 11 \\
\hline Impatiens parviflora & 8 & Centaurea cyanus & 3 & Capsella bursa-pastoris & 10 \\
\hline Echinocystis lobata & 7 & Artemisia absinthium & 2 & Tanacetum vulgare & 10 \\
\hline Medicago sativa & 7 & Carduus acanthoides & 2 & Trisetum flavescens & 10 \\
\hline Solidago canadensis & 7 & Celtis australis & 2 & Chelidonium majus & 9 \\
\hline Amaranthus retroflexus & 6 & Chenopodium ficifolium & 2 & Humulus lupulus & 9 \\
\hline Chamomilla suaveolens & 6 & Chenopodium murale & 2 & Myosotis arvensis & 9 \\
\hline Helianthus tuberosus & 6 & Consolida regalis & 2 & $\begin{array}{l}\text { Chenopodium album agg., } \\
\text { Setaria viridis }\end{array}$ & 8 \\
\hline
\end{tabular}

etation plot we calculated the absolute species richness, mean relative species richness per plot and total cover of archeophytes, neophytes and native species $(11,18,32,33)$. Absolute numbers of alien species and their cover are presented for rough estimation but were not used in further comparisons due to problems of sampling plot size.

We calculated regression and correlation between all three groups of species (neophytes, archaeophytes and natives). For statistical analyses we added 0.5 to species number and then square-root transformed it.

Dataset management was done in Juice program (34) and statistical analyses were performed in Statistica (35).

\section{RESULTS}

In the selected data subset there were 100 neophytes (4.6\%), 54 archaeophytes (2.5\%), and altogether 2182 taxa. Mean percentage of neophytes per vegetation plot is $2.22 \%( \pm 5.16)$, archaeophytes $3.01 \%( \pm 5.76)$, and native species $94.75 \%( \pm 9.21)$.

The highest proportion of alien species (archaeophytes and neophytes) occur on arable land (I1). In addition, archaeophytes occur in higher percentages (about $5 \%$ or more) also in trampled areas, anthropogenic herb stands and moist tall-herb stands. Neophytes are on the other hand highly represented (more than $10 \%$ ) in arable land, trampled areas, but also riverine scrubs and wet and moist tall-herb stands. Habitats with low invasion of alien species are marine and coastal habitats, mires, bogs and fens and high altitude habitats (herb stands and scrubs). Comparison of invaded habitats based on cover does not change their ranking, but moist tall herb stands and standing wa- ters stand out with higher cover of neophytes (e.g. Elodea canadensis, Impatiens glandulifera, Rudbeckia laciniata, Solidago canadensis, S. gigantea) compared to their rather low species proportion. Mesic grasslands have high cover of archaeophytes, mostly due to grass Dactylis glomerata.

Most frequent neophytes in the dataset are: Erigeron annuus, Veronica persica, Galinsoga parviflora, Oxalis fontana, and Solidago gigantea while archeophytes with highest frequency are: Dactylis glomerata, Cirsium arvenses, Cynodon dactylon, Setaria pumila, and Amaranthus lividus. Archaeophytes and neophytes with broadest habitat range are presented in Table 2.

Number of alien species versus native species reveals that alien species numbers are highest in intermediate species rich habitats, while the numbers are lower in extreme cases (species poor or rich habitats). Relationship was not significant for archaeophytes $(\mathrm{r}=0.1202, \mathrm{p}=$ $0.5268)$ and neophytes $(\mathrm{r}=-0.1115, \mathrm{p}=0.5576)$, but polynomial curve indicates slight increase of species number in the centre of $\mathrm{x}$-axis. Both alien species categories are most represented in arable land. Archaeophytes are overrepresented also in woodland fringes and clearings, mesic grasslands, while neophytes in riparian forests, trampled communities, tall herb fringes and surface standing waters (Table 1, Figure 1). On the other hand there was strong relationship between number of archaeophytes and neophytes $(r=0.7243, \mathrm{p}<0.001)$.

\section{DISCUSSION}

Archaeophyte and neophyte species with highest number of occupied habitats in Slovenia were found in 20 
and 17 out of 30 different habitat types respectively (Table 2). The difference between percentages per plot and per dataset is negative for neophytes $(2.2-4.5)$ while for archaeophytes it is positive $(3.0-2.5)$, which indicates that archaeophytes occupy more habitats and plots due to longer residence time because they had more time to disperse and adapt (7). Neophyte species are present in the area for shorter period of time (compared to archaeophytes) and thus all haven't yet become established in all suitable sites (18). Lower occurrence of neophytes in many habitats (and also frequency in particular vegetation plots) is attributed to a lag phase (36) and the increase of neophyte numbers is expected due to new introductions and spreading to many new habitats (anthropogenic and natural) as in other countries (37). By contrast archaeophytes are shifting from anthropogenous to more natural habitats in recent time (13).

The relative proportions of archaeophytes are in most cases higher than that of neophytes across habitat types; notable exceptions are standing waters, riverine scrub and trampled areas. Also, the relationship between the number of archaeophytes and the number of neophytes (Figure 1) is strongly positive which confirms that high number of archaeophyte species is a good predictor for neophytes invasion (18).

Comparing percentages of neophyte species that occur in many habitat types (more than one third) in different vegetation datasets across tested European regions, Slovenia exhibits low value (5\%). The highest proportion is in Great Britain (17.8 \%) but appears much lower in other regions: Czech Republic $9.4 \%$, E Romania $6.7 \%$, and Catalonia $3.7 \%(16,18)$. These results place Slovenia amid the other regions and indicate possible maximum value at about $10 \%$ for continental Europe obtained with this type of data.

Composition of 20 neophyte species, occurring in highest number of habitats in Slovenia, is far more similar to that of E Romanian and Czech lists of species (11 and 10 same species, respectively) while it is very different from the ones of Catalonia and Great Britain (only 3 same species) $(16,18)$, which shows great geographical dependence. Not one species appears on all of the 5 mentioned top lists, but a few appear on four of them, namely $\mathrm{Ve}$ ronica persica, Robinia pseudacacia, Chamomilla suaveolens and Conyza canadensis.

A high number of occupied habitats does not necessarily mean that a species is also invasive in means that it drastically changes natural plant communities; they can only be naturalized and constantly present only with low abundance. The examples in Slovenia beside aforementioned Veronica persica are Oxalis fontana, found in 21 habitat types, and Chamomilla suaveolens, found in 13 habitat types, both considered only potentially invasive (19). On the other hand species such as water plants (Elodea canadensis, Pistia stratiotes), highly constrained by their physiological characteristics, can express substantial abundance in favourable habitat types but cannot invade
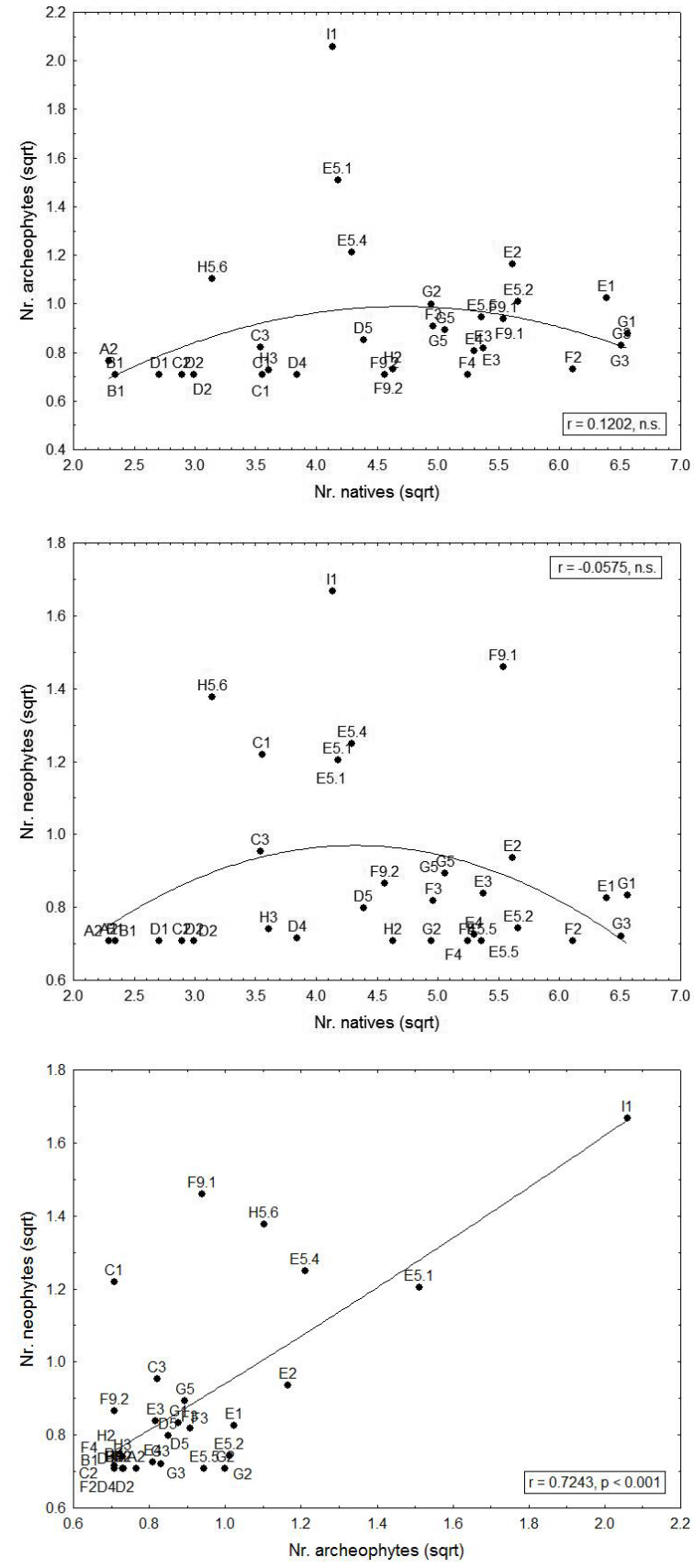

Figure 1. Relationships between mean number of archaeophytes, neophytes and native species in different habitats. Labels refer to EUNIS habitat types (Table 1).

many different ones. Habitat generalists among neophytes are not necessarily invasive species, but the number of habitats in which they occur can provide general information on the magnitude of their potential of invasion (16).

According to surveys based on vegetation data only few neophyte species occurred in the analysed plots from 5 European regions (Catalonia, Czech republic, Great Britain, Slovenia, E Romania), namely: Conyza canadensis, Helianthus tuberosus, Juncus tenuis, Chamomilla sua- 


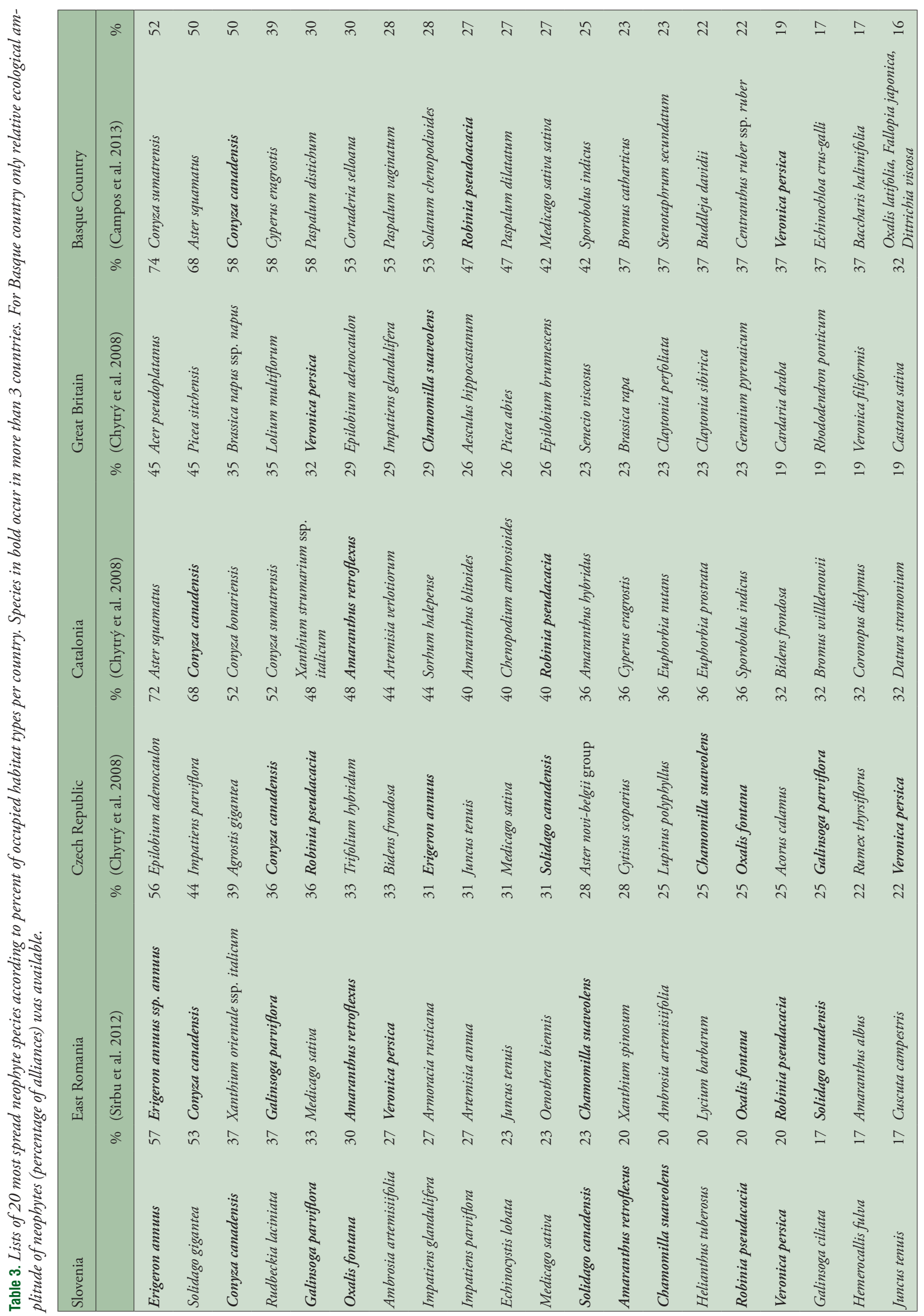


Table 4. Most invaded habitat types by neophytes in different European regions according to vegetation database analyses. Habitat types are listed in decreasing order for particular region.

\begin{tabular}{|c|c|c|c|c|c|c|c|c|}
\hline Slovenia & $\begin{array}{l}\text { Slovakia } \\
\text { (Medvecka et al. } \\
\text { 2014) }\end{array}$ & $\begin{array}{l}\text { E Romania } \\
\text { (Sîrbu et al. 2012) }\end{array}$ & $\begin{array}{l}\text { Basque Country } \\
\text { (Campos et al. } \\
2013 \text { ) }\end{array}$ & $\begin{array}{l}\text { Catalonia } \\
\text { (Chytrý et al. } \\
\text { 2008) }\end{array}$ & $\begin{array}{l}\text { Czech Republic } \\
\text { (Chytrý et al. } \\
\text { 2008) }\end{array}$ & $\begin{array}{l}\text { Great Britain } \\
\text { (Chytrý et al. } \\
2008 \text { ) }\end{array}$ & $\begin{array}{l}\text { NW Poland* } \\
\text { (Myśliwy 2014) }\end{array}$ & $\begin{array}{l}\text { Hungary** } \\
\text { (Botta-Dukát 2009) }\end{array}$ \\
\hline I1 & G1.C & G1.C, G5.2 & A2 & I1 & $\mathrm{H} 3$ & G3 & I1.3 & $\begin{array}{l}\text { Riverine shrublands } \\
\text { and woodlands }\end{array}$ \\
\hline $\mathrm{H} 5.6$ & E5.41 & I1.5, J4, J6.1 & C2.5 \& C3.5 & C3 \& D5 & E5.1 & I1 & H5.6 & $\begin{array}{l}\text { Open sand grasslands } \\
\text { and poplar-juniper } \\
\text { thickets }\end{array}$ \\
\hline E5.4 & E2.8 & I1 & $\begin{array}{l}\text { E5.1 } \\
\text { (Balloto-Conion) }\end{array}$ & H5.6 & $\mathrm{H} 5.6$ & B1 \& B2 & I1.5 & Steppe woodlands \\
\hline $\mathrm{C} 1$ & I1 & E5.4 & G1 & E5.1 & I1 & E5.1 & $\mathrm{J} 4.2$ & $\begin{array}{l}\text { Mesic decidious } \\
\text { woodlands in low- } \\
\text { lands }\end{array}$ \\
\hline E5.1 & E5.1B & E5.6 & E5.4 & B1 \& B2 & $\mathrm{C} 1$ & C3 \& C5 & E1 & $\begin{array}{l}\text { Eu- and mesotrophic } \\
\text { wet meadows and } \\
\text { sedge beds }\end{array}$ \\
\hline F9.1 & G1.1 & H5.6 & $\begin{array}{l}\text { E5.1 } \\
\text { (Galio-Alliarion) }\end{array}$ & F9 & C3 \& C5 & G1 \& G4 & E2 & $\begin{array}{l}\text { Collin and montane } \\
\text { hay meadows }\end{array}$ \\
\hline F9.2 & F3 & $\mathrm{C} 1$ & E2.2 & E3 \& E5.4 & G5 & FA & FA & $\begin{array}{l}\text { Dry and semi-dry } \\
\text { closed grasslands }\end{array}$ \\
\hline C3 & E5.43 & $\mathrm{C} 3, \mathrm{D} 5$ & G1.7 & $\begin{array}{l}\text { A2.5 \& D6 } \\
\& \text { E6 }\end{array}$ & F3 & F3 & E5.1 & $\begin{array}{l}\text { Dry, closed Quercus } \\
\text { woodlands }\end{array}$ \\
\hline E3 & E5.1A & & C $3.3 \&$ E3.1 & $\mathrm{C} 1$ & F9 & E2 & G5.1 & Fens \\
\hline E2 & F9.21 & & $\begin{array}{l}\text { E5.1 } \\
\text { (Convolvulo- } \\
\text { Agropyrion) }\end{array}$ & $\mathrm{H} 2$ & A2 \& D6 \& E6 & E3 \& E5.4 & E5.2 \& E5.4 & $\begin{array}{l}\text { Mesic decidious } \\
\text { woodlands of hills } \\
\text { and mountains }\end{array}$ \\
\hline
\end{tabular}

* Based on floristic list made in EUNIS habitats as sampling unit.

** Based on grouped habitats in wider categories from MÉTA survey.

veolens, Solidago canadensis. It is important to bear in mind that vegetation databases store different data than floras or checklists (often missing casual alien species) and that this can limit the generalization of certain patterns or even lead to misleading conclusions (15). Although alien flora from vegetation plots of the same habitats differs between regions pattern of habitat invasion is determined by the characteristics of the habitat rather than the particular alien plant species (18).

Habitats rich in native species are predicted as also being more invasible $(38,39)$. Habitats with low number of native species indicate sites with environmental conditions that inhibit successful establishment of many native species as well as potential aliens (40). In Slovenia number of neophyte or archaeophyte species per plot are similar to the observed pattern in Catalonia (14) with highest numbers of alien species at intermediate numbers of native species.

Most of the invaded habitats in Slovenia, where on average almost every vegetation plot contains at least one neophyte (surface standing waters, anthropogenic herb stands, moist and wet forbs, riverine scrub, trampled areas and arable land) (Table 1) have also been found as the most invaded in other surveys $(13,15,16,18,41)$. High level of invasion in most of these habitat types is probably a consequence of the intrinsic susceptibility to invasion due to the fluctuating resources (due to lessened competition and/or increased input of resources by natural or anthropogenic means) as hypothesized by Davis, et al.
(42). Beside the habitats own susceptibility an important factor for higher alien species invasion is a strong and/or regular propagule pressure (43).

Differences in most invaded habitats between regions can be interpreted by regional differences in climate, topography and geology $(44)$, land-use history $(45,46)$ and introduction history (47) but also by differences in datasets (e.g. lack of urban habitats in Great Britain dataset, (18)) and scale of study (15).

Pattern across different regions is very similar with anthropogenous habitats being most invaded by alien species. In several countries forests are most invaded. In Slovakia, Romania and Hungary (Table 4) these are Salix dominated forests along rivers that are known as being very prone to invasion of alien species and good corridors for their spread (48). Temperate and boreal softwood riparian woodlands (G1.1) have by far the highest mean levels of invasion per plot among forest habitats in Europe (33). The reason that in Slovenia riparian forests are not as high on the list of invaded habitats is that we did not separate them as a particular category from other deciduous forests (as Chytrý, et al. (18)). Slovenia is the third most forested country in Europe with relatively well preserved forests. Nevertheless analysis of forest stands of Slovenia revealed that riparian forests (Salix and Populus forests) are the most invaded (49). In Slovenia standing waters are high on the list of invaded habitats. In our data set, neophyte species that occur in this habitat type are 
mostly Elodea canadensis and occasionally Rudbeckia laciniata, Solidago canadensis and S. gigantea. Standing waters in the database are presented by plant communities (Nyphaeetum albo-luteae and Ceratophyllo-Nupharetum) in oxbows along Mura river. In Czech Republic the most frequently present neophyte in standing waters is also Elodea canadensis (18). For Slovenia according to floristic records Zelnik (20) states that the species is more common in running waters than in standing ones. Spicer and Catling (50) state that $E$. canadensis is more characteristic of eutrophic standing or slowly running waters (ponds, accumulation lakes, ditches) but a survey of the species in Slovenian watercourses (51) did not show that it is very invasive, but the invasion by $E$. nuttallii is expected (20). It seems $E$. canadensis mostly occupies standing waters, though it does not yet exhibit a tendency to cover larger surfaces. Special case of invasion of this habitat in Slovenia is Pistia stratiotes that survives in thermal stream (52) but this habitat is not included in vegetation database.

Coastal habitats are in Slovenia limited to few protected areas and the rest of the coast is highly urbanized by port industry and intensive tourism. Saline habitats are very prone to alien invasion but coastal regions can differ considerably in the level of the invasion. Coastal communities of Basque country are the most invaded habitat while saline habitats in Catalonia are less invaded and in Great Britain less invaded even in comparison to inland halophytic habitats in Czech Republic (Table 4). As saline habitats in Slovenia are localised and not open to free visit there is less disturbance and possible propagule pressure. Floristic data from Slovenia highlight only Aster squamatus and Robinia pseudoaccacia as invasive species in coastal wetlands $(20)$.

\section{CONCLUSION}

The results of the invasion level across different habitat types using data from the Slovenian vegetation database show great similarity with other regions in Europe. Most invaded habitat types are those under strong human influence - arable land, trampled areas, anthropogenic herb stands; and some (semi-)natural habitats: riverine scrub and wet and moist tall herb stands. The composition of top most spread alien species is more similar to geographically closer regions (E Romania, Czech Republic) and a lot different than in more distant ones (Great Britain, Catalonia). Regarding the percentage of alien species that occur in more than a third of habitat types results place Slovenia amid other continental regions in Europe. Changes in the ratios (especially regarding neophytes) will be important for future research.

\section{Acknowledgements}

We thank two anonymous reviewers for valuable comments that substantially improved the manuscript. The research was financed by ARRS through research program (P1-0236).

\section{REFERENCES}

1. RICHARDSON DM, PYŠEK P, REJMÁNEK M, BARBOUR MG, PANETTA FD, WEST CJ 2000 Naturalization and invasion of alien plants: concepts and definitions. Diversity and distributions 6: 93-107

2. PYŠEK P, RICHARDSON D M 2012 Invasive species. In: CRAIG RK, NAGLE JC, PARDY B, SCHMITZ O, SMITH W (ed) Berkshire Encyclopaedia of Sustainability. Vol. 5: Ecosystem Management and Sustainability. Berkshire Publishing Group, Great Barrington, MA, p 211-219

3. PRESTON CD, PEARMAN DA, HALLAR 2004 Archaeophytes in Britain. Botanical Journal of the Linnean Society 145: 257-294 https://doi.org/10.1111/j.1095-8339.2004.00284.x

4. PYŠEK P, SÁDLO J, MANDÁK B 2002 Catalogue of alien plants of the Czech Republic. Preslia 74: 97-186

5. LAMBDON PW, PYŠEK P, BASNOU C, HEJDA M, ARIANOUTSOU M, ESSL F, JAROŠÍK V, PERGL J, WINTER M, ANASTASIU P, ANDRIOPOULOS P, BAZOS I, BRUNDU G, CELESTI-GRAPOW L, CHASSOT P, DELIPETROU P, JOSEFSSON M, KARK S, KLOTZ S, KOKKORIS Y, KÜHN I, MARCHANTE H, PERGLOVÁ I, PINO J, VILÁ M, ZIKOS A, ROY D, HULME P E 2008 Alien flora of Europe: species diversity, temporal trends, geographical patterns and research needs. Preslia 80: 101-149

6. HOLZNER W 1978 Weed species and weed communities. Vegetatio 38: 13-20. https://doi.org/10.1007/BF00141295

7. WILLIAMSON M, DEHNEN-SCHMUTZ K, KÜHN I, HILL M, KLOTZ S, MILBAU A, STOUT J, PYŠEK P 2009 The distribution of range sizes of native and alien plants in four European countries and the effects of residence time. Diversity and Distributions 15: 158-166

https://doi.org/10.1111/j.1472-4642.2008.00528.x

8. COMIN S, POLDINI L 2009 Archaeophytes: Decline and dispersal - A behavioural analysis of a fascinating group of species. Plant Biosystems 143: S46-S55.

https://doi.org/10.1080/11263500903192159

9. ZAJĄC M, ZAJĄC A, TOKARSKA-GUZIK B 2009 Extinct and endangered archaeophytes and the dynamics of their diversity in Poland. Biodiversity: Research and Conservation 13: 17-24. https:// doi.org/10.2478/v10119-009-0004-4

10. PYŠEK P, CHYTRÝ M 2014 Habitat invasion research: where vegetation science and invasion ecology meet. Journal of Vegetation Science 25: 1181-1187. https://doi.org/10.1111/jvs.12146

11. CHYTRÝ M, PYŠEK P, TICHÝ L, KNOLLOVÁ I, DANIHELKA J 2005 Invasions by alien plants in the Czech Republic: a quantitative assessment across habitats. Preslia 77: 339-354

12. MASKELL LC, FIRBANK LG, THOMPSON K, BULLOCK JM, SMART SM 2006 Interactions between non-native plant species and the floristic composition of common habitats. Journal of Ecology 94: 1052-1060

13. MEDVECKÁ J, JAROLÍMEK I, SENKO D, SVITOK M 2014 Fifty years of plant invasion dynamics in Slovakia along a 2,500 m altitudinal gradient. Biological Invasions 16: 1627-1638. https://doi.org/10.1007/s10530-013-0596-7

14. VILÀ M, PINO J, FONT X 2007 Regional assessment of plant invasions across different habitat types. Journal of Vegetation Science 18: 35-42. https://doi.org/10.1111/j.1654-1103.2007.tb02513.x

15. CAMPOS JA, BIURRUN I, GARCIA-MIJANGOS I, LOIDI J, HERRERA M 2013 Assessing the level of plant invasion: A multiscale approach based on vegetation plots. Plant Biosystems 147: 1148-1162

16. SÎRBU C, OPREA A, SAMUIL C, TĂNASE C 2012 Neophyte Invasion in Moldavia (Eastern Romania) in Different Habitat Types. Folia Geobotanica 47: 215-229. https://doi.org/10.1007/s12224-011-9112-y

17. BOTTA-DUKÁT Z 2008 Invasion of alien species to Hungarian (semi-)natural habitats. Acta Botanica Hungarica 50 (suppl. 1): 219227. https://doi.org/10.1556/ABot.50.2008.Suppl.11 
18. CHYTRÝ M, MASKELL LC, PINO J, PYŠEK P, VILÀ M, FONT X, SMART SM 2008 Habitat invasions by alien plants: a quantitative comparison among Mediterranean, subcontinental and oceanic regions of Europe. Journal of Applied Ecology 45: 448-458

19. JOGAN J, BAČIČ M, STRGULC KRAJŠEK S 2012 Tujerodne in invazivne rastline v Sloveniji. In: JOGAN J, BAČIČ M, STRGULC KRAJŠEK S (ed) Neobiota Slovenije, končno poročilo projekta. Oddelek za biologijo BF UL, Ljubljana, p 161-182

20. ZELNIK I 2012 The presence of invasive alien plant species in different habitats: case study from Slovenia. Acta biologica Slovenica 55: $25-38$

21. ŠILC U 2010 Synanthropic vegetation: pattern of various disturbances on life history traits. Acta Botanica Croatica 69: 215-225

22. ŠILC U 2015 Biotic homogenization and differentiation in weed vegetation over the last 70 years. Open life sciences 10: 537-545

23. ŠILC U, ČARNI A, VRBNIČANIN S, BOŽIĆ D, DAJIĆ STEVANOVIC Z 2012 Alien plant species and factors of invasiveness of anthropogenic vegetation in the Northwestern Balkans - a phytosociological approach. Central European Journal of Biology 7: 720-730. https://doi.org/10.2478/s11535-012-0049-9

24. ŠILC U 2012 Vegetation database of Slovenia. Biodiversity \& Ecology 4: 428. https://doi.org/10.7809/b-e.00215

25. WRABER M 1969 Pflanzengeographische Stellung und Gliederung Sloweniens. Vegetatio 17: 176-199. https://doi.org/10.1007/BF01965908

26. ARSO 2006 Podnebne razmere v Sloveniji (obdobje 1971 - 2000). Agencija Republike Slovenije za okolje, Ljubljana, p 27

27. ŠILC U, ČARNI A 2012 Conspectus of vegetation syntaxa in Slovenia. Hacquetia 11: 113-164.

https://doi.org/10.2478/v10028-012-0006-1

28. MARTINČIČ A, WRABER T, JOGAN N, PODOBNIK A, RAVNIK V, TURK B, VREŠ B, FRAJMAN B, STRGULCKRAJŠEK S, TRČAK B, BAČIČ T, FISCHER MA, ELER K, SURINA B 2007 Mala flora Slovenije: ključ za določanje praprotnic in semenk. Tehniška založba Slovenije, Ljubljana, p 845

29. HENNEKENS SM, SCHAMINÉE JHJ 2001 TURBOVEG, a comprehensive data base management system for vegetation data. Journal of Vegetation Science 12: 589-591. https://doi.org/10.2307/3237010

30. BRAUN-BLANQUET J 1964 Pflanzensoziologie. Grundzüge der Vegetationskunde. Springer Verlag, Wien, p 865. https://doi.org/10.1007/978-3-7091-8110-2

31. SCHAMINÉE JHJ, CHYTRÝ M, HENNEKENS SM, MUCINA L, RODWELL JS, TICHÝ L 2012 Development of vegetation syntaxa crosswalks to EUNIS habitat classification and related data sets. Final report EEA/NSV/12/001. Alterra, Wageningen, p 135

32. CATFORD JA, VESK PA, RICHARDSON DM, PYŠEK P 2012 Quantifying levels of biological invasion: towards the objective classification of invaded and invasible ecosystems. Global change biology 18: 44-62

33. WAGNER V, CHYTRÝ M, JIMÉNEZ-ALFARO B, PERGL J, HENNEKENS S, BIURRUN I, KNOLLOVÁ I, BERG C, VASSILEV K, RODWELL JS, ŠKVORC Ž, JANDT U, EWALD J, JANSEN F, TSIRIPIDIS I, BOTTA-DUKÁT Z, CASELLA L, ATTORRE F, RAŠOMAVIČIUS V, ĆUŠTEREVSKA R, SCHAMINÉE JHJ, BRUNET J, LENOIR J, SVENNING J-C, KĄCKI Z, PETRÁŠOVÁ-ŠIBÍKOVÁ M, ŠILC U, GARCÍAMIJANGOS I, CAMPOS JA, FERNÁNDEZ-GONZÁLEZ F, WOHLGEMUTH T, ONYSHCHENKO V and PYŠEK P 2017 Alien plant invasions in European woodlands. Diversity and Distributions 1-13

34. TICHÝ L 2002 JUICE, software for vegetation classification. Journal of Vegetation Science 13: 451-453. https://doi.org/10.1111/j.1654-1103.2002.tb02069.x

35. STATSOFT I 2007 STATISTICA (data analysis software system), version 8.0. www.statsoft.com.
36. KOWARIK I 1995 Time-lags in biological invasions. In: PYŠEK P, PRACH K, REJMANEK M, WADE M (ed) Plant invasions. General aspects and special problems. SPB Academic Publishing, Amsterdam, p 15-38

37. AIKIO S, DUNCAN RP, HULME PE 2012 The vulnerability of habitats to plant invasion: disentangling the roles of propagule pressure, time and sampling effort. Global Ecology and Biogeography 21: 778-786. https://doi.org/10.1111/j.1466-8238.2011.00711.x

38. LONSDALE WM 1999 Global patterns of plant invasions and the concept of invasibility. Ecology 80: 1522-1536.

https://doi.org/10.1890/0012-9658(1999)080[1522:GPOPIA]2.0. $\mathrm{CO} ; 2$

39. STOHLGREN TJ, BARNETT DT, KARTESZ JT 2003 The rich get richer: patterns of plant invasions in the United States. Frontiers in Ecology and the Environment 1: 11-14. https://doi.org/10.1890/1540-9295(2003)001[0011:TRGRPO]2.0. $\mathrm{CO} ; 2$

40. DAVIS MA 2009 Invasion Biology. OUP Oxford, p

41. MYŚLIWY M 2014 Plant invasions across different habitat types at floristic survey. Applied Ecology and Environmental Research 12: 193-207. https://doi.org/10.15666/aeer/1201_193207

42. DAVIS MA, GRIME JP, THOMPSON K 2000 Fluctuating resources in plant communities: a general theory of invasibility. Journal of Ecology 88: 528-534

43. CHYTRÝ M, JAROŠÍK V, PYŠEK P, HÂJEK O, KNOLLOVÁ I, TICHÝ L, DANIHELKA J 2008 Separating habitat invasibility by alien species from the actual level of invasion. Ecology 89: 15411553. https://doi.org/10.1890/07-0682.1

44. GASSÓ N, PINO J, FONT X, VILÀ M 2012 Regional context affects native and alien plant species richness across habitat types. Applied Vegetation Science 15: 4-13. https://doi.org/10.1111/j.1654-109X.2011.01159.x

45. MOSHER ES, SILANDER JA, LATIMER AM 2009 The role of land-use history in major invasions by woody plant species in the northeastern North American landscape. Biological Invasions 11: 2317. https://doi.org/10.1007/s10530-008-9418-8

46. PARKS CG, RADOSEVICH SR, ENDRESS BA, NAYLOR BJ, ANZINGER D, REW LJ, MAXWELL BD, DWIRE KA 2005 Natural and land-use history of the Northwest mountain ecoregions (USA) in relation to patterns of plant invasions. Perspectives in Plant Ecology, Evolution and Systematics 7: 137-158

47. BUCHAROVA A, VAN KLEUNEN M 2009 Introduction history and species characteristics partly explain naturalization success of North American woody species in Europe. Journal of Ecology 97: 230-238. https://doi.org/10.1111/j.1365-2745.2008.01469.x

48. RICHARDSON DM, HOLMES PM, ESLER KJ, GALATOWITSCH SM, STROMBERG JC, KIRKMAN SP, PYŠEK P, HOBBS RJ 2007 Riparian vegetation: degradation, alien plant invasions, and restoration prospects. Diversity and distributions 13 : 126-139

49. DAKSKOBLER I, KUTNAR L, ŠILC U, VREŠ B 2017 Prisotnost in pogostnost tujerodnih rastlinskih vrst $\mathrm{v}$ gozdnih rastiščnih tipih Slovenije. In: JURC M (ed) Invasive alien species in forests and their impact on the sustainable use of forest resources, XXXIII. Forestry Study Days. Ljubljana, p 125-142

50. SPICER KW, CATLING PM 1988 The biology of Canadian weeds. 88. Elodea canadensis Michx. Canadian Journal of Plant Science 68: 1035-1051. https://doi.org/10.4141/cjps88-125

51. KUHAR U, GERM M, GABERŠČIK A 2010 Habitat characteristics of the alien species Elodea canadensis in Slovenian watercourses. Hydrobiologia 656: 205-212. https://doi.org/10.1007/ s10750-010-0438-x

52. ŠAJNA N, HALER M, ŠKORNIK S, KALIGARIČ M 2007 Survival and expansion of Pistia stratiotes $L$. in a thermal stream in Slovenia. Aquatic Botany 87: 75-79. https://doi.org/10.1016/j. aquabot.2007.01.012 
Appendix: All neophytes and archaeophytes in vegetation of Slovenia that occur in different EUNIS habitat types. Species are sorted alphabetically. ?-marks doubtful archaeophytes that were not included into analyses.

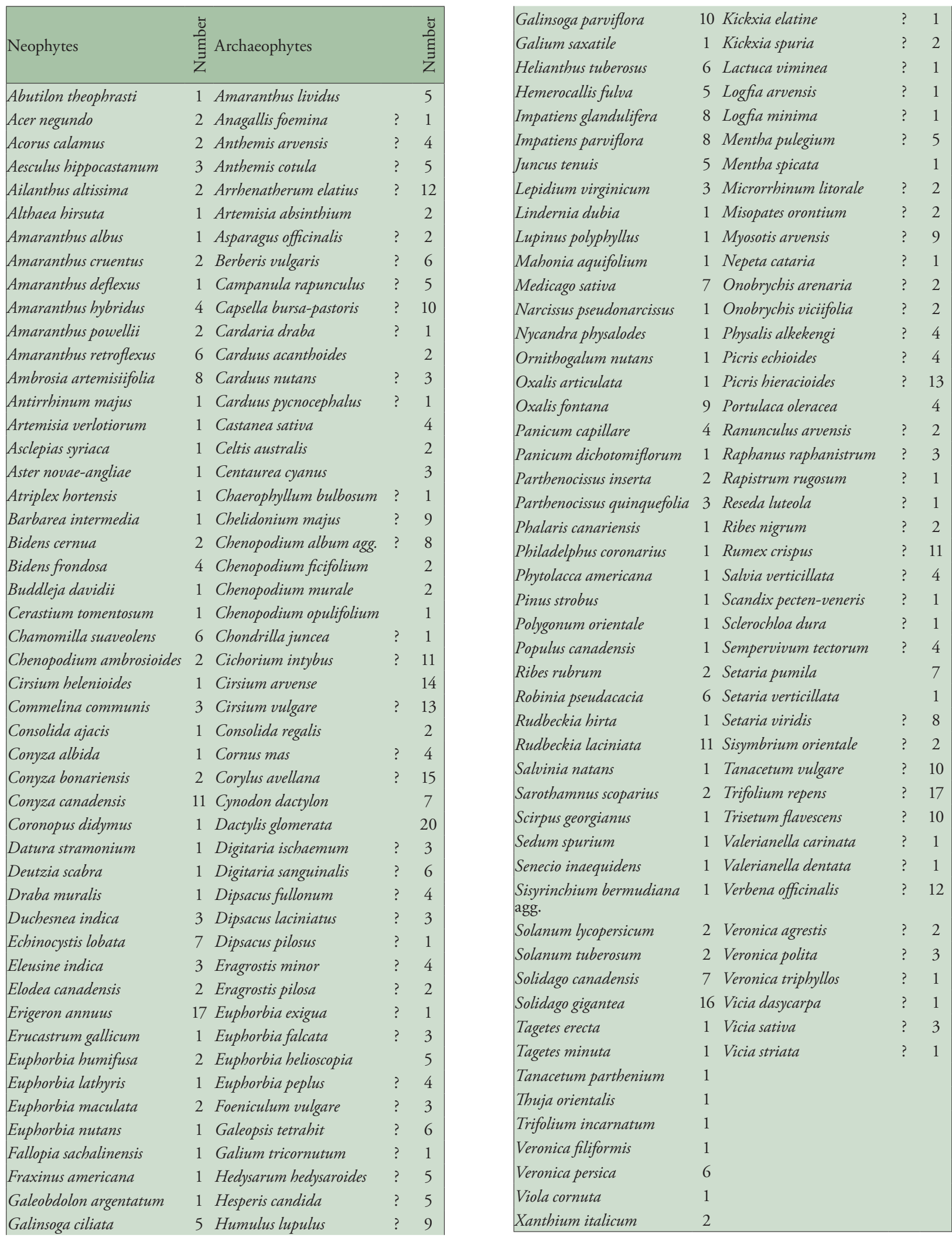

